\title{
IMPROVEMENT OF TECHNOLOGY OF INDUSTRIAL WASTEWATER TREATMENT THE ENTERPRISES PRODUCING VEGETABLE OILS
}

\author{
Kulikova D.V. \\ National Technical University «Dnipro Polytechnic» \\ D. Yavornytrskyi av. 19, 49005, Dnipro \\ kulikova.d.v@nmu.one
}

\begin{abstract}
The wastewater composition of the enterprises producing vegetable oils includes a variety of organic and inorganic compounds, including fatty substances. Depending on the conditions of formation and composition of wastewater, fats can be in the form of a fatty phase, which forms a thin film on the surface of the liquid, dispersed particles in water (emulsion) and be in a soluble state. Fats, entering to water sources, create favourable conditions for the development of many simple organisms and bacteria, which subsequently cause secondary pollution of water bodies. In addition, wastewater, in which the permissible fat content is significantly exceeded, causes serious damage to sewage systems. In the presence of increased concentrations of fatty deposits in wastewater, the problem arises of operating centralized sewage disposal systems and further wastewater treatment at special facilities. Therefore, it is extremely necessary to neutralize wastewater before it is discharged from the treatment facilities of the enterprise, since further treatment takes place on urban sewage systems, which receive wastewater according to strictly limited indicators, which become more and more stringent every year. To date, the most common method is wastewater treatment from fatty substances using a mechanical grease trap. When using grease traps as local treatment facilities, it is impossible to reduce the concentration of fats to the established standards only by sedimentation methods. The article proposes to improve the technology of industrial wastewater treatment the enterprises producing vegetable oils through the use of aerated grease traps and coagulants to reduce the fat content to the standard values, which are set by water utilities for the purpose of further wastewater treatment in centralized sewage disposal systems. The introduction of the proposed technology makes it possible to significantly reduce the fat content in wastewater after purification in aerated grease traps with the addition of coagulants, the final concentration of which will not exceed the approved standards $-10-20 \mathrm{mg} / \mathrm{dm}^{3}$. In addition, the content of suspended solids and organic pollutants is reduced in wastewater after purification using the proposed technology. Key words: enterprises producing vegetable oils, waste water, fatty substances, aerated grease trap, coagulants, water quality standards.
\end{abstract}

Удосконалення технології очищення виробничих стічних вод підприємств, що виробляють рослинні олії. Кулікова Д.В.

Склад стічних вод підприємств олійно-екстракційної промисловості містить різноманітні органічні та неорганічні сполуки, зокрема жирові речовини. Залежно від умов утворення і складу стічних вод жири можуть бути у вигляді жирової фази, що створює на поверхні рідини плівку, або диспергованих часточок у воді (емульсія) та знаходитись у розчинному стані. Жири, надходячи до водних джерел, утворюють сприятливе середовище для розвитку безлічі найпростіших організмів і бактерій, які згодом спричинюють вторинне забруднення водойм. Окрім того, стічні води, в яких виявлено перевищення допустимої норми вмісту жирів, наносять суттєву шкоду каналізаційним системам. За наявності у стічних водах жирових залишків у підвищених концентраціях виникає проблема експлуатації систем централізованого водовідведення і подальшого очищення стічних вод на спеціальних спорудах. Тому вкрай необхідно знешкодити стічні води перед їхнім випуском з очисних споруд підприємства, оскільки подальше очищення відбувається на міських системах каналізації, які приймають стоки за строго лімітованими показниками, котрі з кожним роком стають все більш жорсткими.

Нині найпоширенішим методом є очищення стічних вод від жирових речовин за допомогою механічного жировловлювача. За застосування в якості локальних очисних споруд жировловлювачів неможливо знизити концентрації жирів до встановлених норм тільки шляхом відстоювання. У статті запропоновано вдосконалити технологію очищення виробничих стоків олійно-екстракційних підприємств за рахунок застосування аерованих жировловлювачів та коагулянтів задля зниження вмісту жирів до нормативних значень, що встановлюються водоканалами з метою подальшої обробки стічних вод у системах централізованого водовідведення. Впровадження запропонованої технології дозволить значно знизити вміст жирів у стічних водах після очищення в аерованих жировловлювачах з додаванням коагулянтів, кінцева концентрація яких не перевищуватиме затверджених нормативів - 10-20 мг/дм³. Окрім того, у стічних водах після очищення за запропонованою технологією знижується вміст завислих речовин та органічних забруднень. Ключові слова: підприємства олійно-екстракційної промисловості, стічні води, жирові речовини, аерований жировловлювач, коагулянти, нормативи якості води.

Formulation of the problem. The food industry is one of the strategic sectors of the economy, which should ensure a sustainable supply of the population with the necessary quality food.

Modern food production has a negative impact on the ecological state of the environment, and its concentration in large settlements - on the living conditions and health of the population.
Food industry enterprises are characterized by high specific water consumption and discharge of the heavily polluted wastewater.

The composition of wastewater from food enterprises includes surfactants, fats, oils, lubricants, hydrocarbons, organic acids, which when dissolved in water are subject to biological oxidation [1]. These substances, getting into water bodies, form a thin layer on the water 


\section{Kulikova D.V.}

surface, which prevents gas exchange between water and the atmosphere and reduces the degree of oxygen saturation of water.

Research topicality. Requirements for the content of both organic and inorganic pollutants in surface water and wastewater are very strict. This is due to the fact that during their accumulation, sanitary and hygienic indicators of water quality deteriorate.

The absence or imperfection of the industrial wastewater treatment methods, and sometimes violation of the rules for the protection of water bodies, is the reason for their pollution with substances of various origins.

The problem of wastewater treatment from food enterprises is quite acute; therefore this paper is devoted to the improvement of methods for their purification and increase of water quality, which is discharged for further processing into the systems of centralized sewage disposal of the settlements.

Relation of copyright work with important scientific and practical tasks. The maximum permissible concentrations of pollutants discharged into the municipal sewage network, establish harsh requirements for the qualitative composition of wastewater to receive them from industrial enterprises and organizations [2]. This is due to the fact that sewer networks can be clogged, grown over with fatty deposits, and treatment facilities purifying municipal wastewater cannot cope with cleaning. Fats just belong to this category of pollutants that affect the operation of municipal sewage networks and treatment facilities.

In the technological scheme of wastewater treatment of enterprises producing vegetable oils, a separate processing of fat-containing effluents is required. Their pre-cleaning is mandatory before discharge of wastewater in the city sewage network for further biological treatment of production effluents together with municipal wastewater.

The introduction of the proposed technology makes it possible to significantly reduce the fat content in wastewater after purification in aerated grease traps with the addition of coagulants, the final concentration of which will not exceed the approved standard values which are set by water utilities with the aim of further wastewater treatment in centralized sewage systems of the settlements. In addition, the content of suspended solids and organic pollutants is reduced in wastewater after purification using the proposed technology.

Analysis of recent research and publications. Facilities for primary (mechanical, physicochemical, electrochemical) and secondary (biological) purification are used for the wastewater treatment containing a significant amount of organic substances $[3,4]$.

Mechanical treatment is used to extract insoluble compounds from wastewater. Grids, sieves, sand traps, sedimentation tanks, grease traps, and various filters are used at this stage of purification [5].

Almost all enterprises producing vegetable oils have workshop or yard grease traps for primary wastewater
IMPROVEMENT OF TECHNOLOGY...

treatment [6]. Now the grease traps of various modifications are used. The duration of wastewater treatment in them is from 15 to 30 minutes. The removal of fatty substances is carried out using a mechanical and mechanized method.

Of the physicochemical methods of wastewater treatment from fatty substances is most often used flotation, sorption, as well as processing with reagents [7-9]. The most often for the sewage treatment of the food industry used the method of the pressure reagent flotation.

To increase the efficiency of wastewater treatment, containing fatty substances before flotation, the method of treating effluents by reagents is used. The wastewater treatment with coagulants and flocculants improves the process of extraction of suspended particles and colloids by their concentration in the form of flakes (flocul), with subsequent separation in systems settling, flotation and/or filtration.

Despite the advantages, all the reagent methods are characterized by general disadvantages, namely: the need for reagents, low efficiency when there are several types of pollution, sensitivity to changes in technology, difficulties in the further implementation of products formed after purification. This leads to the accumulation of fatty deposits and, ultimately, to the shutdown of the treatment facilities.

Currently, in addition to the physical and physicochemical methods of wastewater treatment, containing in its composition of fats, the biological method based on the activity of microorganisms - destructors of the fatty substances is widely used [10].

Biological wastewater treatment has a number of major advantages compared to other methods. Microorganisms make a complete decomposition of pollutants to gaseous products and water, thereby providing a circulation of elements in nature. Thus, during biological treatment, unlike other methods, does not concentrate concentration of contaminants or their conversion into another form. At the same time, the biological methods are most economical, since with the exception of large capital investments, practically do not require costs during the operation of the facilities, and the main component of biological purification is the active sludge which has the ability to renew.

Selection of previously unresolved tasks of the general problem. Conventional grease traps, which are installed at the food industry enterprises, in most cases do not provide required of defatting due to the special conditions for the distribution of fat in the form of thin layers on the water surface. The effectiveness of their purification in the content of fat substances, even when complying with the necessary sedimentation time is approximately $40-50 \%$ [5]

Fats and organic pollutants that enter the centralized sewage systems along with wastewater form deposits on the inner wall of the pipes, which disrupt the uninterrupted and efficient operation of sewage network. As a result, the throughput of pipes decreases, clogging 
and fat plugs constantly occur, emergency situations are created, and treatment facilities cannot cope with cleaning. In addition, the resulting fat plugs are a favorable environment for the development of putrefactive microorganisms that cause unpleasant odors. Therefore, enterprises are forced to implement the regular cleaning of industrial sewage. That is why the water utilities establish strict requirements for the quality composition of wastewater, which is discharged into the municipal sewer network from enterprises and organizations.

The purpose of the paper is to improve the technology of wastewater treatment the enterprises producing vegetable oils through the use of aerated grease traps and coagulants to reduce the fat content to standards that meet the requirements for the wastewater discharge from these industrial facilities into the municipal sewage network.

The research novelty refers to improvement of the technology of wastewater treatment the enterprises producing vegetable oils through to use of aerated grease traps and coagulants makes it possible to extract from wastewater not only fats of vegetable and animal origin, but also suspended solids and organic compounds, which are among the priority pollutants for enterprises in this sector of the national economy.

Methodological or general scientific significance. Compliance with the "Rules of wastewater reception into the systems of centralized sewage of the settlements" through the introduction of the proposed technology of wastewater treatment the enterprises producing vegetable oils prevents the formation of fatty deposits on the walls of pipes, ensuring the uninterrupted and efficient operation of sewage networks and treatment facilities at the biological treatment stations of the municipal wastewater.

Outline of the main material. In the enterprises producing vegetable oils, a large number of technological operations are carried out, as a result of which different types of pollution are formed [11]. Wastewater is formed from water separators and sludge evaporators located in the extraction department, from grease traps, departments of hydration, refining and oil packaging. In the oil-pressed workshop, wastewater is formed when cleaning of the oil on the separators. In addition, wastewater is formed as a result of the condensation of water vapor in capacitors and deflegmators.

The wastewater volume depends on the type of the source of oil producing and technology, which is used [12]. In the processes of producing and refining of edible oil, may be formed to $1.5 \mathrm{~m}^{3}$ of wastewater per 1 ton of oil.

Depending on the species, method, conditions of processing of fatty raw materials and technological operations, various types of fatty substances may be in wastewater. The wastewater of the enterprises producing vegetable oils include fatty acids, as well as glycerides, gasoline, phosphatides, soaps, alkalis and other concomitant substances [11].
Wastewater of the vegetable fats refining enterprises for edible oil production consists mainly from emulsions of contaminated fats, stabilized soaps derived from fats and fatty acids. In addition, the wastewater contains organic acids and substances containing nitrogen, which, after neutralization, rot, forming hydrogen sulfide from proteins that are decompose and sulfates that are reduced [11].

Wastewater from enterprises producing vegetable oils is cloudy, gray in color, and contains a suspension in the form of flakes.

Wastewater odor is unpleasant, the oxidizability is low (49-354 $\mathrm{mgO}_{2} / \mathrm{dm}^{3}$ ). The dry residue is $44-5000 \mathrm{mg} / \mathrm{dm}^{3}$. The active reaction of the medium $(\mathrm{pH})$ is 6-7, the index of biological oxygen consumption $\left(\mathrm{BOC}_{5}\right)$ is $300-520 \mathrm{mg} / \mathrm{dm}^{3}$, the fat content is up to $400 \mathrm{mg} / \mathrm{dm}^{3}$. The fat is most often present in the form of vegetable oils, small amounts of which cover the water mirror, complicating re-aeration and dissolution of oxygen [12].

Adverse contaminants in wastewater from enterprises producing vegetable oils are the index of biological oxygen consumption (BOC) and a large amount of fats and suspended solids.

For enterprises which discharge wastewater containing fats after local treatment into the centralized sewage systems of the settlements, water utilities establish maximum permissible concentrations (MPC) for fat content [2]. As a rule, MPCs for fats are set in the range of $10-20 \mathrm{mg} / \mathrm{dm}^{3}$. For exceeding of the discharge standards the penalties are imposed.

When grease traps are used as local treatment facilities at the enterprises producing vegetable oils, it is impossible to reduce the concentration of fats to the established standards only by sedimentation. In this case, the final concentration of fats at the outlet from the grease trap is on average $50 \mathrm{mg} / \mathrm{dm}^{3}$.

For enterprises producing vegetable oils, from the point of view of the best available technologies with respect to reducing the content of fatty substances in industrial wastewater, two main directions can be distinguished [11].

The first direction is associated with the improvement of existing technological processes through the introduction of certain types of equipment, which, with a sufficiently high output of the finished product, can reduce emissions into the environment and the consumption of various types of energy.

The second direction is associated with the introduction of the technologies that completely exclude the most dangerous processes in terms of the formation of emissions and discharges.

The difficulty of solving the problem of industrial wastewater treatment is due to the variability of their composition, the variety of physical and chemical processes underlying their treatment, large capital and operating costs for the construction and maintenance of treatment complexes and individual wastewater facilities. 


\section{Kulikova D.V.}

The centralized sewage system of the city can receive industrial waste water that does not disrupt the operation of sewer networks and treatment facilities, ensure the safety of their operation and can be rendered harmless together with the municipal water of the settlement in accordance with the requirements and standards $[2,13,14]$.

Requirements for the composition of industrial wastewater [2], which are discharged into the municipal sewer network, dictate the need to develop new treatment schemes, to intensify the operation of existing treatment facilities.

The latter can be ensured both by improving existing constructions and by additional implementation of new effective units in the technological scheme, which provide the necessary degree of wastewater treatment from a certain pollutant.

To increase the efficiency of the treatment facilities of the municipal sewer network, it is proposed to improve the technology of the wastewater treatment containing fatty substances at the enterprises producing vegetable oils. Namely, the use of aerated grease traps and coagulants.

Aerated grease traps [15] are indirect flotation facilities that effectively purified wastewater from cutting fluids after washing parts and assemblies, demonstrate a high degree of wastewater treatment from vegetable and animal fats, oils, various petroleum products, surfactants, synthetic surfactants and other insoluble pollutants, the specific gravity of which is less than the specific gravity of water. The facilities are also designed

\section{IMPROVEMENT OF TECHNOLOGY...}

for wastewater treatment from sand, suspended solids, rubbers and iron.

This facility can be used for wastewater treatment of oil depots, oil refineries, oil and fat production enterprises, meat processing plants, fish and dairy factories, etc.

The general scheme of a treatment facility with an aerated grease trap is shown in Fig. 1.

The advantages of aerated grease traps include the fact that they provide the highest cleaning level among alternative options, economical. They also have a significant service life, the lack of unpleasant odors. In addition, the installation does not require frequent cleansing.

Partitions which separate chambers of the facility have a continuous perforation and can be disconnect for cleaning as needed.

The chamber from which the purified water is discharged is separated from other compartments the solid partition. Water removal is carried out from the lower level, where the cleanest water is located.

In aerated grease traps, air is used to intensify the process of removal of lightweight substances from contaminated wastewater. Air, passing through the layer of wastewater, captures the fat particles and raises them on the surface. In addition, the saturation of sewage by oxygen contributes to the aerobic oxidation of organic substances.

Flotation is applied additionally in this construction. Due to this, surfactants, fats, petroleum products, resins and others are extracted from wastewater.

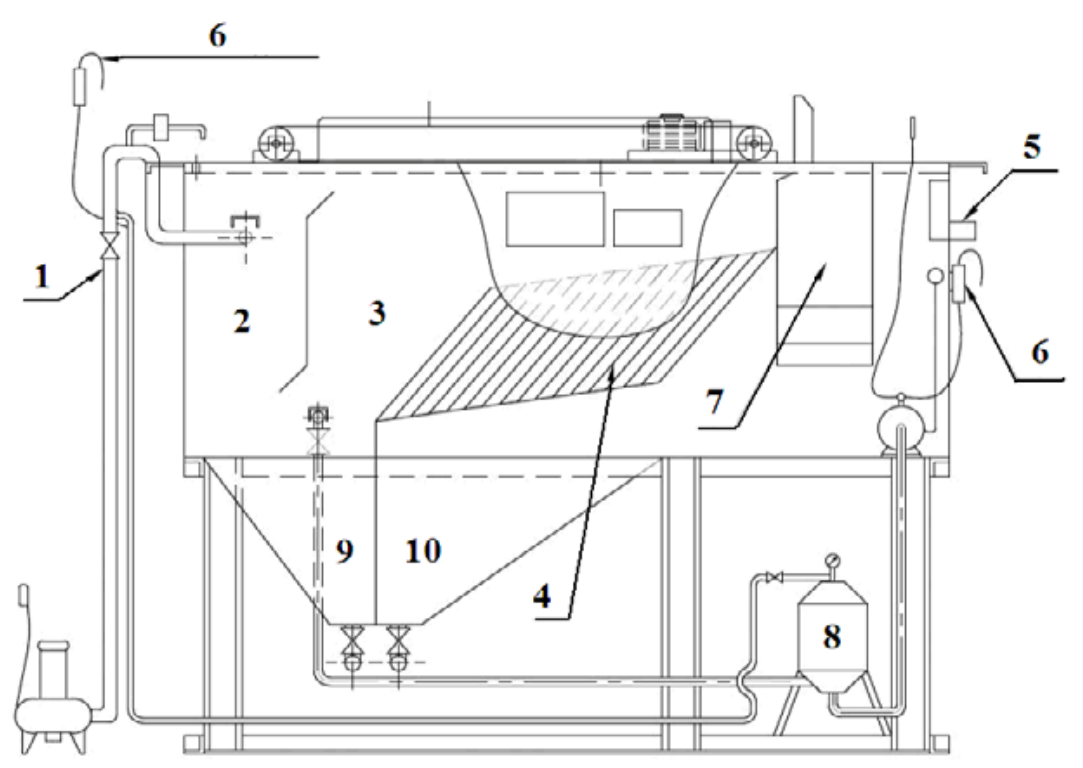

Fig. 1. The general scheme of the treatment facility with an aerated grease trap

1 - supply of wastewater containing fatty substances; 2 - pre-flotation and sedimentation chamber; 3 - flotation chamber; 4 - thin-layer block; 5 - purified water discharge; 6 - reagent injection points; 7 - sludge collection tray; 8 - saturator; 9 - primary sedimentation tank; 10 - secondary sedimentation tank 
The best results on the wastewater treatment containing fats and other organic pollutants, were achieved in the aerated grease traps due to the additional use of coagulants, namely chlorine iron $\left(\mathrm{FeCl}_{3}\right)$ and aluminum sulfate $\left(\mathrm{Al}_{2}\left(\mathrm{SO}_{4}\right)_{3}\right)$. The use of chlorine iron in doses of 300 $\mathrm{mg} / \mathrm{dm}^{3}$ with further deposition for 30 minutes makes it possible to obtain a transparent liquid at the outlet of the aerated grease trap [16].

It should be noted that the supply of wastewater to the aerated grease trap and directly to the flotation is carried out by different pumps (the supply of wastewater can be carried out by gravity). This solution makes it possible to increase the permissible concentration of pollutants at the inlet to the treatment facility. This reduces the risk of tripping pumps. For the supply of wastewater, a fecal pump is selected, which is designed for high concentrations of pollutants and for the implementation of the flotation process, a pump is selected that ensures good mixing of oxygen with water. The resistance of the flotation pump to contamination fades into the background, because it operates in a chamber with purified water. Thus, indirect flotation avoids excessive mixing, emulsification of effluents at the inlet to the aerated grease trap and improves the quality of the water-air mixture on a separate flotation pump.

All this leads to an increase the efficiency of wastewater treatment, in comparison with treatment facilities that exist at the enterprises producing vegetable oils. The efficiency of industrial wastewater treatment containing fats in its composition after aerated grease traps is $90-98 \%$. In addition, in the wastewater after purification in an aerated grease trap, the content of suspended solids and the index of biological oxygen consumption decrease (wastewater treatment efficiency is $80-95 \%$ and $40-85 \%$, respectively) [17].

Only after thorough pretreatment, wastewater of the enterprises producing vegetable oils is sent to municipal wastewater treatment facilities for further biological treatment.

Conclusions. In the paper solved actual practical problem, which is to improve the technology of wastewater treatment the enterprises producing vegetable oils through the use of aerated grease traps and coagulants to reduce the fat content to values of maximum permissible concentrations, which are set by water utilities with the aim of further wastewater treatment in the centralized sewage systems of the settlements.

The proposed wastewater treatment facility performs three main functions: extraction of the fat dissolved in water and sediments, which are in a suspended state; reduction of the amount of organic pollution and bottom sediments; the absence of the appearance of putrid odors. These functions are the optimal set which allows obtaining the maximum effect of the wastewater treatment with minimum maintenance.

Indirect flotation facilities are well established as a preliminary stage before biological treatment. In addition to removing a significant part of the pollutants, wastewater is saturated with dissolved oxygen, as a result of which the oxidative processes in aeration tanks and biological filters are intensified during further biological wastewater treatment at the stations of the municipal sewer network.

Thus, the improvement of wastewater treatment technology containing fatty substances, at the enterprises producing vegetable oils, reduces the fat content of more than 10 times (up to $2-10 \mathrm{mg} / \mathrm{dm}^{3}$ ), which meet the standards for discharge of wastewater at the stations of the biological treatment of municipal sewage.

Perspectives for the further use of research results. The introduction of the proposed technology of industrial wastewater treatment the enterprises producing vegetable oils makes it possible to significantly reduce the fat content in the wastewater after purification in aerated grease traps with the addition of coagulants, the final concentration of which will not exceed the approved standards which are set by water utilities with the aim of further wastewater treatment in the centralized sewage systems of the settlements. In addition, the content of suspended solids and organic pollutants is reduced in wastewater after purification using the proposed technology. In turn, this will prevents the formation of fatty deposits on the walls of pipes, ensuring the uninterrupted and efficient operation of the sewage networks and treatment facilities at the stations of the biological treatment of municipal wastewater.

\section{References}

1. Каца В.М. Вода и сточные воды в пищевой промышленности. Москва: Издательство «Пищевая промышленность», 1992. $384 \mathrm{c}$.

2. Про затвердження Правил приймання стічних вод підприємств до систем централізованого водовідведення та Порядку визначення розміру плати, що справляється за понаднормативні скиди стічних вод до систем централізованого водовідведення: Наказ Міністерства регіонального розвитку, будівництва та житлово-комунального господарства України від 01.12.2017 p. №316.

3. Гіроль М.М., Гіроль А.М., Гіроль А.М. Технології водовідведення промислових підприємств: навчальний посібник. Рівне: НУВГП, 2013. $625 \mathrm{c.}$

4. Запольський А.К. Водовідведення, водопостачання та якість води: навчальний посібник. Київ: Вища школа, 2005.671 с.

5. Гудков А.Г. Механическая очистка сточных вод: учебное пособие. Вологда: ВоГТУ, 2003. 152 с.

6. Мачигин В.С., Щербакова Л.П. Очистка сточных вод предприятий масло-жировой промышленности. Масложировая промышленность. 1992. №1. С. 30-34.

7. Маркитанова Л.И., Кисс В.В., Каверзнева Т.Т. Водоснабжение и очистка сточных вод предприятий пищевой промышленности: учебное пособие. СПб.: СПбГУНиПТ, 2006. 134 с. 


\section{Kulikova D.V.}

IMPROVEMENT OF TECHNOLOGY...

8. Благодарная Г.И., Шевченко А.А., Лунин С.В. Анализ методов очистки высококонцентрированных сточных вод предприятиями пищевой промышленности. Коммунальное хозяйство городов. 2011. №93. С. 176-182.

9. Лоренц В.И. Очистка сточных вод предприятий пищевой промышленности. Київ: «Будівельник», 1972.188 с.

10. Яковлев С.В., Скирдов И.В., Швецов В.Н., Бондарев А.А., Андрианов Ю.Н. Биологическая очистка производственных сточных вод. Процессы, аппараты и сооружения. Монография. Москва: Стройиздат, 1985. 208 с.

11. Информационно-технический справочник по наилучшим доступным технологиям ИТС 44-2017 «Производство продуктов питания». Москва: Бюро НДТ, 2017. 436 с.

12. Укрупненные нормы водопотребления и водоотведения для различных отраслей промышленности. Москва: Стройиздат, $1978.590 \mathrm{c}$.

13. Про затвердження Правил охорони поверхневих вод від забруднення зворотними водами: Постанова Кабінету Міністрів України від 25 березня 1999 р. №465.

14. Про затвердження Правил користування системами централізованого комунального водопостачання та водовідведення в населених пунктах України: Наказ Міністерства з питань житлово-комунального господарства України від 27.06.2008 p. № 190 .

15. Воронов Ю.В., Яковлев С.В. Водоотведение и очистка сточных вод: учебник для вузов. Москва: Изд-во Ассоциации строительных вузов, 2006. 704 с.

16. Марочкин А.А., Спиридонова Л.Г., Лесников И.И., Гетманцев С.В. Технологические схемы очистки концентрированных производственных сточных вод. Экология промышленности. 2009. № 6. С. 73-75.

17. Каталог-перечень оборудования. Оборудование вспомогательное систем водоснабжения и водоотведения. КПО-07.03.09-06. Москва, 2006. 158 с. 